\title{
Optimalisasi Terminal Tipe A Bandar Raya Payung Sekaki Kota Pekanbaru Provinsi Riau
}

\author{
Anggi Pratama*, Tonny Judiantono \\ Prodi Teknik Perencanaan Wilayah \& Kota, Fakultas Teknik, \\ Universitas Islam Bandung, Indonesia. \\ *anggipratama898@gmail.com, tonny@unisba.ac.id
}

\begin{abstract}
Terminal Type A Bandar Raya Payung Sekaki is the largest terminal in the city of Pekanbaru and Riau Province with quite volatile arrival and departure movements. The current condition of the BRPS Terminal is not as expected because there are still many passengers who are reluctant to get on and off at the terminal because the location of the terminal is quite far from the center of activities such as the center of trade, socio-economic and other activities so that there is a lack of movement through the BRPS Terminal. The analytical method used is qualitative and quantitative analysis. Qualitative analysis is used to describe current conditions such as system activity conditions, terminal utilization, terminal accessibility and SWOT. While the quantitative analysis is IPA analysis, movement and passenger potential analysis using growth factors and terminal income potential analysis. From the results of the SWOT analysis, it is stated that the terminal is in quadrant I (aggressive). From the results of the IPA, there are 15 service indicators that need to be improved. From the analysis of potential demand, there are $25.34 \%$ additional passengers for AKDP and $41.61 \%$ for AKAP. From the results of the analysis of potential income has a potential income of Rp. 569,250,000/year of potential land lease. Based on the analysis of potential demand and income, the terminal has great potential to be optimized. Terminal optimization is carried out by improving terminal services, increasing terminal accessibility and connectivity
\end{abstract}

Keywords: Bus Terminal, Optimization, Accessibility.

Abstrak. Terminal Tipe A Bandar Raya Payung Sekaki merupakan terminal terbesar di kota Pekanbaru dan Provinsi Riau dengan pergerakan kedatangan dan keberangkatan yang cukup fluktuatif. Kondisi Terminal BRPS saat ini tidak seperti yang diharapkan karena masih banyak penumpang yang enggan naik dan turun di terminal karena lokasi terminal berada cukup jauh dari pusat kegiatan seperti pusat perdagangan, sosial ekonomi dan kegiatan lainnya sehingga kurangnya pergerakan yang melewati Terminal BRPS. Metode analisis yang digunakan adalah analisis kualitatif dan kuantitatif. Analisis kualitatif digunakan untuk menggambarkan kondisi terkini seperti kondisi sistem aktivitas, pemanfaatan terminal, aksesibilitas terminal dan SWOT. Sedangkan analisis kuantitatif yaitu analisis IPA, analisis potensi pergerakan dan penumpang menggunakan growth factor dan analisis potensi pendapatan terminal. Dari hasil analisis SWOT menyatakan terminal berada di kuadran I (agresif). Dari hasil IPA terdapat 15 indikator pelayanan yang perlu ditingkatkan. Dari hasil analisis potensi demand terdapat penambahan penumpang AKDP 25,34\% dan AKAP 41,61\%. Dari hasil analisis potensi pendapatan memiliki pendapatan potensial sebesar Rp. 569.250.000/tahun dari sewa lahan potensial. Berdasarkan hasil analisis potensi demand dan pendapatan maka terminal memiliki potensi yang besar untuk dioptimalkan. Optimalisasi terminal dilakukan dengan cara meningkatan pelayanan terminal, meningkatan aksesibilitas dan konektivitas terminal

Kata Kunci: Terminal Bis, Optimalisasi, Aksesibilitas. 


\section{A. Pendahuluan}

Berkembangnya suatu kota, sejatinya berpengaruh terhadap pola kehidupan masyarakat dari berbagai bidang atau aspek kehidupan. Perencanaan tata ruang kota akan selalu mengalami proses dinamika yang terus menerus dan berkesinambungan, yang mana ruang harus memberikan keberlanjutan untuk pemanfaatannya. Kebijakan tata ruang sangat erat kaitannya dengan kebijakan transportasi, dan ruang merupakan kegiatan yang ditempatkan di atas lahan kota, sedangkan transportasi merupakan jaringan yang secara fisik menghubungkan satu ruang dengan ruang kegiatan yang lainnya. Bila akses transportasi ke antar ruang (lahan) dibentuk dan ditata maka ruang kegiatan tersebut akan menjadi menarik dan menjadi lebih berkembang.

Terminal sebagai simpul dalam jaringan transportasi memegang peran penting bagi kelancaran jaringan transportasi karena sesuai dengan fungsi dari terminal adalah pangkalan kendaraan bermotor umum yang digunakan untuk mengatur kedatangan dan keberangkatan, menaikan dan menurunkan orang dan/atau barang, serta perpindahan moda angkutan (Permenhub Nomor 132 Tahun 2015)

Terminal yang ada di Indonesia masih perlu banyak pembenahan dan perhatian khusus, sebagaimana jumlahnya yang kurang memadai dari aspek kualitas pelayanan prasarana, integrasi dan infrastruktur tersebut cukup memprihatinkan. Terminal Tipe A BRPS Kota Pekanbaru mulai beroperasi pada tahun 2006 yang menggantikan fungsi terminal mayang terurai dengan alasan pemindahan keterbatasan lahan. Pada perkembangan nya pergerakan penumpang di terminal BRPS cenderung fluktuatif dan tidak mengalami perkembangan yang berarti seperti pada saat lokasi terminal masih ditengah kota dan dekat dengan permukiman penduduk

Berdasarkan latar belakang yang telah diuraikan, maka pertanyaan penelitian dalam penelitian ini sebagai berikut: "bagaimana mengupayakan pengoptimalan terminal pada pelayanan dan bagaimana mengupayakan peningkatan demand terminal?". Selanjutnya tujuan dalam penelitian ini ialah untuk "mengoptimalkan Terminal Tipe A BRPS Kota Pekanbaru dari sisi peningkatan demand dan pelayanan terminal dengan standar pelayanan minimal terminal"

\section{B. Metodologi Penelitian}

Metode pengumpulan data diperoleh dari data primer dan data sekunder dengan mengkombinasikan beberapa teknik diantaranya; survey lapangan dan instasional, interview, penyebaran kuesioner dan studi literatur

Untuk menghasilkan penilaian pelayanan terminal dapat digunakan dengan metode Importance Performance Analysis (IPA), penelitian dimulai dengan survei pendahuluan, idetifikasi masalah, studi literatur, penentuan metode pengumpulan data, penentuan populasi, sampel penyusunan kuesioner, analisis data serta penarikan kesimpulan dan rekomendasi berupa upaya pengoptimalan terminal. Berdasarkan Permenhub No.40 Tahun 2015 tentang standar pelayanan terminal penumpang angkutan jalan [7] terdapat 6 standar pelayanan terminal yang diejawantahkan ke dalam 6 variabel dan 41 indikator yang digunakan pada analisi IPA [1]. Berikut variabel dan indikator standar pelayanan terminal penumpang pada Tabel 1.

Tabel 1. Indikator Standar Pelayanan Terminal

\begin{tabular}{|c|c|c|}
\hline No & Variabel/indikator Pelayanan & Notasi \\
\hline \multicolumn{3}{|c|}{ Keselamatan } \\
\hline 1 & Jalur Pejalan Kaki & a.1 \\
\hline 2 & Fasilitas Keselamatan Jalan & a.2 \\
\hline 3 & Jalur Evakuasi & a.3 \\
\hline 4 & Alat Pemadam Kebakaran & a.4 \\
\hline 5 & Pos, Fasilitas Dan Petugas Kesehatan & a.5 \\
\hline 6 & Pos, Fasilitas Dan Kelaikan Pemeriksa Kendaraan Umum & a.6 \\
\hline 7 & Fasilitas Perbaikan Ringan Kendaraan Umum & a.7 \\
\hline 8 & Informasi Fasilitas Keselamatan & a.8 \\
\hline 9 & Informasi Fasilitas Kesehatan & a.9 \\
\hline 10 & Informasi Fasilitas Pemeriksaan Dan Perbaikan Ringan Kendaraan Bermotor & a.10 \\
\hline \multicolumn{3}{|c|}{ Keamanan } \\
\hline 11 & Fasilitas Keamanan & b.1 \\
\hline 12 & Media Pengaduan Gangguan Keamanan & b.2 \\
\hline
\end{tabular}




\begin{tabular}{|c|c|c|}
\hline No & Variabel/indikator Pelayanan & Notasi \\
\hline 13 & Petugas Keamanan & b.3 \\
\hline \multicolumn{3}{|c|}{ Kehandalan/Keteraturan } \\
\hline 14 & $\begin{array}{l}\text { Jadwal Kedatangan Dan Keberangkatan Kendaraan Serta Besar Tarif Kendaraan Bermotor Umum Beserta } \\
\text { Realisasi Jadwal Secara Tertulis }\end{array}$ & c. 1 \\
\hline 15 & $\begin{array}{l}\text { Jadwal Kendaraan Umum Dalam Trayek Lanjutan Dan Kendaraan Umum Tidak Dalam Trayek Lanjutan } \\
\text { Beserta Realisasi Jadwal Secara Tertulis }\end{array}$ & c. 2 \\
\hline 16 & Loket Penjualan Tiket & c. 3 \\
\hline 17 & Kantor Penyelenggara Terminal, Ruang Kendali Dan Manajemen Sistem Informasi Terminal & c. 4 \\
\hline 18 & Petugas Operasional Terminal & c.5 \\
\hline \multicolumn{3}{|c|}{ Kenyamanan } \\
\hline 19 & Ruang Tunggu & d.1 \\
\hline 20 & Toilet & d.2 \\
\hline 21 & Fasilitas Peribadatan & d.3 \\
\hline 22 & Ruang Terbuka Hijau & d.4 \\
\hline 23 & Rumah Makan & d.5 \\
\hline 24 & Fasilitas dan Petugas Kebersihan & d.6 \\
\hline 25 & Tempat Istirahat Awak Kendaraan & d.7 \\
\hline 26 & Area Merokok & d.8 \\
\hline 27 & Drainase & d.9 \\
\hline 28 & Area Yang Tersedia Jaringan Interner & d.10 \\
\hline 29 & Ruang Baca & d.11 \\
\hline 30 & Lampu Penerangan Ruang & d.12 \\
\hline \multicolumn{3}{|c|}{ Kemudahan/Keterjangkauan } \\
\hline 31 & Letak jalur Pemberangkatan & e. 1 \\
\hline 32 & Letak Jallur Kedatangan & e. 2 \\
\hline 33 & Informasi Pelayanan & e. 3 \\
\hline 34 & Informasi Angkutan Jalan & e.4 \\
\hline 35 & Informasi Gangguan Perjalanan Kendaraan Angkutan Umum & e.5 \\
\hline 36 & Tempat Penitipan Barang & e.6 \\
\hline 37 & Fasilitas Pengisian Baterai & e.7 \\
\hline 38 & Tempat Naik dan Turun Penumpang & e. 8 \\
\hline 39 & Tempat Parkir Kendaraan Umum dan Kendaraan Pribadi & e. 9 \\
\hline \multicolumn{3}{|c|}{ Kesetaraan } \\
\hline 40 & Fasilitas Penyandang Cacat & f.1 \\
\hline 41 & Ruang Ibu Menyusui & f.2 \\
\hline
\end{tabular}

Sumber: Permenhub No.40 Tahun 2015

Sampel pada penelitian ini adalah masyarakat yang berada didalam kawasan terminal yang dikelompokan menjadi 3 yaitu penumpang terminal, supir bis dan operator terminal baik yang menggunakan AKDP dan AKAP. Sampel bersifat purposive dengan jumlah sampel penumpang bis berjumlah 30, supir bis berjumlah 38 (sesuai per trayek yang ada) dan 52 operator bis (sesuai jumlah operator yang ada).

Hasil pengumpulan data kuesioner kemudian dianalisis dengan tahapan pertama menghitung hasil dan rata - rata kepuasan dan kepentingan pelayanan terminal setelah itu menentukan tingkat kesesuaian antara kepentingan dan kepuasan atribut - atribut yang diteliti melalui perbandingan skor kepuasan dan kepentingan. Rumus tingkat kesesuaian ialah

Keterangan :

$$
\mathrm{Tki}=\frac{X i}{Y i} \times 100
$$

Tki = tingkat kesesuaian

$\mathrm{Xi}=$ skor penilaian kinerja

$\mathrm{Yi}=$ skor penilaian kepentingan

Selanjutnya menghitung rata - rata seluruh atribut tingkat kepentingan (Y) dan kepuasan $(\mathrm{X})$ yang menjadi batas dalam diagram kartesius. Tahapan terakhir yaitu penjabaran tiap atribut dalam diagram kartesius seperti Gambar 1. 
118 | Anggi Pratama, et al.

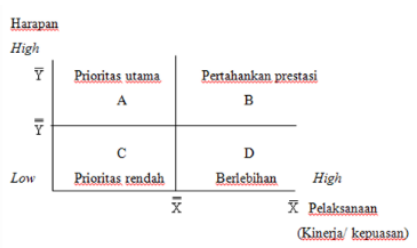

Gambar 1. Diagram Kartesius

Metode analisis selanjutnya yang digunakan dalam penelitian ini adalah analisis komparatif yang digunakan untuk membandingkan persamaan dan perbedaan dua atau lebih fakta - fakta dan sifat - sifat objek yang diteliti, selanjutnya ada analisis SWOT yang digunakan untuk menganalisa kekuatan, kelemahan, peluang dan ancaman terhadap terminal agar dapat menentukan arah strategi kebijakan pengembangan terminal. Selanjutnya analisis yang digunakan ialah analisis potensi demand dan potensi pendapatan yang bertujuan untuk menghasilkan data potensi terminal di masa yang akan datang sebagai dasar dalam mengupayakan pengoptimalan terminal.

\section{Hasil Penelitian dan Pembahasan}

\section{Analisis IPA}

Tingkat kesesuaian merupakan hasil perbandingan antara skor kinerja pelaksanaan dengan skor kepentingan sehingga dapat digunakan untuk menentukan skala prioritas[12]. Tingkat kesesuaian antara skor kepuasan dengan skor kepentingan pada responden penumpang, supir bis dan operator bis dapat dilihat pada Tabel.2,3 dan 4

Tabel 2. Tingkat Kesesuaian Persepsi Penumpang Terminal

\begin{tabular}{|c|c|c|c|c|}
\hline No & Variabel/ Indikator & Tingkat Kepuasan (Xi) & Tingkat Kepentingan(Yi) & Tingkat Kesesuaian (\%) \\
\hline \multirow[t]{9}{*}{1} & \multicolumn{4}{|c|}{ Keselamatan } \\
\hline & a.1 & 87 & 103 & 84.47 \\
\hline & a.2 & 89 & 110 & 80.91 \\
\hline & a.4 & 76 & 126 & 60.32 \\
\hline & a.5 & 91 & 117 & 77.78 \\
\hline & a.6 & 67 & 109 & 61.47 \\
\hline & a. 8 & 80 & 112 & 71.43 \\
\hline & a.9 & 91 & 113 & 80.53 \\
\hline & a. 10 & 68 & 112 & 60.71 \\
\hline \multirow[t]{3}{*}{2} & \multicolumn{4}{|c|}{ Keamanan } \\
\hline & b. 1 & 128 & 134 & 95.52 \\
\hline & b. 2 & 124 & 124 & 100.00 \\
\hline \multirow{4}{*}{3} & c. 2 & 78 & 114 & 68.42 \\
\hline & c. 3 & 83 & 115 & 72.17 \\
\hline & c. 4 & 91 & 112 & 81.25 \\
\hline & c. 5 & 89 & 112 & 79.46 \\
\hline \multirow[t]{7}{*}{4} & \multicolumn{4}{|c|}{ Kenyamanan } \\
\hline & d.1 & 68 & 122 & 55.74 \\
\hline & d.2 & 71 & 122 & 58.20 \\
\hline & d. 3 & 115 & 122 & 94.26 \\
\hline & d.4 & 58 & 122 & 47.54 \\
\hline & d.5 & 78 & 122 & 63.93 \\
\hline & d.6 & 88 & 118 & 74.58 \\
\hline \multirow{3}{*}{5} & e. 1 & 112 & 112 & 78.57 \\
\hline & e. 2 & 111 & 111 & 80.18 \\
\hline & e. 3 & 109 & 109 & 80.73 \\
\hline
\end{tabular}




\begin{tabular}{|c|c|r|r|r|}
\hline No & Variabel/Indikator & Tingkat Kepuasan (Xi) & Tingkat Kepentingan(Yi) & \multicolumn{1}{c|}{ Tingkat Kesesuaian (\%) } \\
\hline \multirow{4}{*}{} & e.4 & 105 & 105 & 83.81 \\
\cline { 2 - 6 } & e.5 & 105 & 105 & 75.24 \\
\cline { 2 - 6 } & e.6 & 131 & 131 & 43.51 \\
\cline { 2 - 6 } & e.7 & 127 & 127 & 60.63 \\
\cline { 2 - 6 } & e.8 & 113 & 113 & 76.11 \\
\hline \multirow{3}{*}{6} & e.9 & 115 & 115 & 79.13 \\
\cline { 2 - 6 } & f.1 & 87 & 97 & 89.69 \\
\cline { 2 - 6 } & f.2 & 88 & 98 & 89.80 \\
\hline
\end{tabular}

Tabel 3. Tingkat Kesesuaian Persepsi Supir Bis Terminal

\begin{tabular}{|c|c|c|c|c|}
\hline No & Variabel/ Indikator & Tingkat Kepuasan (Xi) & Tingkat Kepentingan(Yi) & Tingkat Kesesuaian (\%) \\
\hline \multirow[t]{11}{*}{1} & \multicolumn{4}{|c|}{ Keselamatan } \\
\hline & a.1 & 114 & 132 & 86.36 \\
\hline & a.2 & 112 & 147 & 76.19 \\
\hline & a.3 & 76 & 152 & 50.00 \\
\hline & a.4 & 106 & 151 & 70.20 \\
\hline & a.5 & 114 & 150 & 76.00 \\
\hline & a.6 & 100 & 147 & 68.03 \\
\hline & a.7 & 76 & 153 & 49.67 \\
\hline & a.8 & 110 & 151 & 72.85 \\
\hline & a.9 & 115 & 148 & 77.70 \\
\hline & a.10 & 78 & 152 & 51.32 \\
\hline \multirow[t]{4}{*}{2} & \multicolumn{4}{|c|}{ Keamanan } \\
\hline & b. 1 & 159 & 162 & 98.15 \\
\hline & b. 2 & 153 & 160 & 95.63 \\
\hline & b. 3 & 156 & 163 & 95.71 \\
\hline \multirow[t]{6}{*}{3} & \multicolumn{4}{|c|}{ Kehandalan/Keteraturan } \\
\hline & c. 1 & 104 & 140 & 74.29 \\
\hline & c. 2 & 103 & 140 & 73.57 \\
\hline & c. 3 & 112 & 149 & 75.17 \\
\hline & c. 4 & 114 & 151 & 75.50 \\
\hline & c. 5 & 114 & 152 & 75.00 \\
\hline \multirow[t]{13}{*}{4} & \multicolumn{4}{|c|}{ Kenyamanan } \\
\hline & d.1 & 108 & 154 & 70.13 \\
\hline & d. 2 & 100 & 153 & 65.36 \\
\hline & d. 3 & 147 & 154 & 95.45 \\
\hline & d.4 & 79 & 146 & 54.11 \\
\hline & d.5 & 112 & 153 & 73.20 \\
\hline & d.6 & 115 & 150 & 76.67 \\
\hline & d.7 & 75 & 147 & 51.02 \\
\hline & d.8 & 84 & 131 & 64.12 \\
\hline & d.9 & 114 & 148 & 77.03 \\
\hline & d.10 & 72 & 157 & 45.86 \\
\hline & d.11 & 89 & 98 & 90.82 \\
\hline & d.12 & 113 & 136 & 83.09 \\
\hline \multirow[t]{10}{*}{5} & \multicolumn{4}{|c|}{ Kemudahan/ Keterjangkauan } \\
\hline & e. 1 & 113 & 145 & 77.93 \\
\hline & e. 2 & 113 & 146 & 77.40 \\
\hline & e. 3 & 115 & 143 & 80.42 \\
\hline & e. 4 & 114 & 143 & 79.72 \\
\hline & e.5 & 95 & 122 & 77.87 \\
\hline & e.6 & 77 & 150 & 51.33 \\
\hline & e.7 & 109 & 152 & 71.71 \\
\hline & e. 8 & 110 & 152 & 72.37 \\
\hline & e. 9 & 114 & 152 & 75.00 \\
\hline \multirow[t]{3}{*}{6} & \multicolumn{4}{|c|}{ Kesetaraan } \\
\hline & f.1 & 106 & 133 & 79.70 \\
\hline & f.2 & 112 & 130 & 86.15 \\
\hline
\end{tabular}


Tabel 4. Tingkat Kesesuaian Persepsi Operator Bis Terminal

\begin{tabular}{|c|c|c|c|c|}
\hline No & Variabel/ Indikator & Tingkat Kepuasan (Xi) & Tingkat Kepentingan(Yi) & Tingkat Kesesuaian (\%) \\
\hline \multirow[t]{11}{*}{1} & \multicolumn{4}{|c|}{ Keselamatan } \\
\hline & a.1 & 145 & 179 & 81.01 \\
\hline & a.2 & 155 & 206 & 75.24 \\
\hline & a.3 & 103 & 208 & 49.52 \\
\hline & a.4 & 154 & 209 & 73.68 \\
\hline & a.5 & 169 & 206 & 82.04 \\
\hline & a.6 & 134 & 207 & 64.73 \\
\hline & a.7 & 107 & 206 & 51.94 \\
\hline & a.8 & 153 & 204 & 75.00 \\
\hline & a.9 & 162 & 206 & 78.64 \\
\hline & a.10 & 110 & 207 & 53.14 \\
\hline \multirow[t]{4}{*}{2} & \multicolumn{4}{|c|}{ Keamanan } \\
\hline & b.1 & 230 & 232 & 99.14 \\
\hline & b. 2 & 229 & 231 & 99.13 \\
\hline & b. 3 & 230 & 232 & 99.14 \\
\hline \multirow[t]{6}{*}{3} & \multicolumn{4}{|c|}{ Kehandalan/Keteraturan } \\
\hline & c. 1 & 141 & 201 & 70.15 \\
\hline & c. 2 & 141 & 200 & 70.50 \\
\hline & c. 3 & 183 & 208 & 87.98 \\
\hline & c. 4 & 185 & 206 & 89.81 \\
\hline & c. 5 & 186 & 206 & 90.29 \\
\hline \multirow[t]{13}{*}{4} & \multicolumn{4}{|c|}{ Kenyamanan } \\
\hline & d.1 & 160 & 208 & 76.92 \\
\hline & d.2 & 160 & 208 & 76.92 \\
\hline & d.3 & 201 & 209 & 96.17 \\
\hline & d.4 & 107 & 204 & 52.45 \\
\hline & d.5 & 153 & 207 & 73.91 \\
\hline & d.6 & 172 & 209 & 82.30 \\
\hline & d.7 & 102 & 198 & 51.52 \\
\hline & d.8 & 104 & 172 & 60.47 \\
\hline & d.9 & 156 & 207 & 75.36 \\
\hline & d.10 & 91 & 218 & 41.74 \\
\hline & d.11 & 107 & 124 & 86.29 \\
\hline & d.12 & 154 & 191 & 80.63 \\
\hline \multirow[t]{10}{*}{5} & \multicolumn{4}{|c|}{ Kemudahan/ Keterjangkauan } \\
\hline & e. 1 & 175 & 204 & 85.78 \\
\hline & e. 2 & 175 & 204 & 85.78 \\
\hline & e. 3 & 168 & 204 & 82.35 \\
\hline & e. 4 & 147 & 203 & 72.41 \\
\hline & e. 5 & 109 & 167 & 65.27 \\
\hline & e.6 & 103 & 211 & 48.82 \\
\hline & e.7 & 153 & 208 & 73.56 \\
\hline & e. 8 & 184 & 205 & 89.76 \\
\hline & e.9 & 185 & 206 & 89.81 \\
\hline \multirow[t]{3}{*}{6} & \multicolumn{4}{|c|}{ Kesetaraan } \\
\hline & f. 1 & 129 & 180 & 71.67 \\
\hline & f. 2 & 156 & 182 & 85.71 \\
\hline
\end{tabular}

Setelah menghitung rata - rata tiap variabel dan indikator berdasarkan tingkat kepuasan dan kepentingan kemudian seluruh nilai rata - rata kepuasan dan nilai rata rata kepentingan ini di rata rata kan kembali untuk menghasilkan nilai untuk sumbu X dan sumbu Y pada diagram kartesius. Berikut Gambar 2, 3 dan 4 hasil diagram kartesius penumpang, supir bis dan operator bis: 


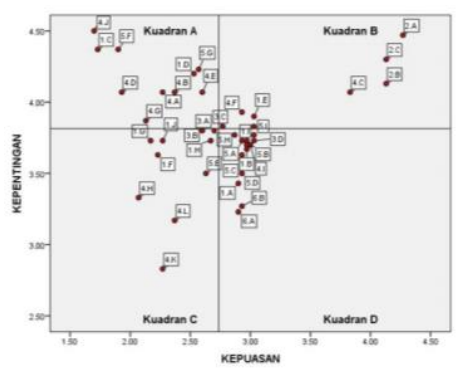

Gambar 2. Diagram Kartesius Responden Penumpang

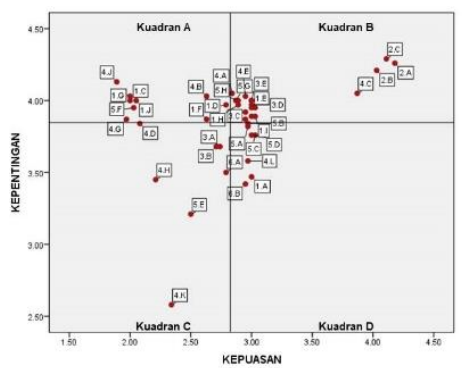

Gambar 3. Diagram Kartesius Responden Supir Bis

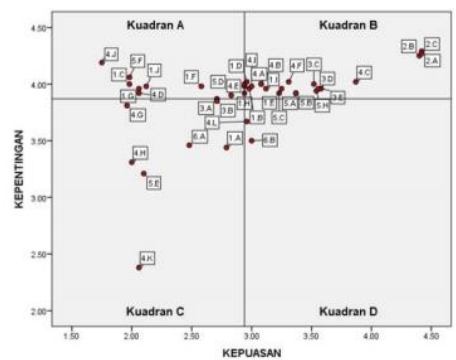

Gambar 4. Diagram Kartesius Responden Operator Bis

Berdasarkan diagram kartesius diatas maka dapat diinterpretasikan bahwa Kuadran A menunjukkan faktor atau atribut yang dianggap penting oleh pengguna namun tidak terlaksana, Kuadran B menunjukkan faktor atau atribut yang dianggap penting dan memuaskan pengguna yang sudah dilaksanakan oleh pengelola, Kuadran C menunjukkan faktor yang dianggap kurang penting oleh pengguna dan tidak terlaksana oleh pengelola, Kuadran D menunjukkan faktor atau atribut yang dianggap kurang penting oleh pengguna dan dilaksanakan dengan baik oleh pengguna.

Berikut Tabel. 5 hasil kuadran diagram kartesius;

Tabel 5. Hasil Diagram Kartesius

\begin{tabular}{|c|c|c|c|c|c|}
\hline \multirow{2}{*}{ No } & \multirow{2}{*}{ Responden } & \multicolumn{4}{|c|}{ Hasil Diagram Kartesius } \\
\hline & & Kuadran A & Kuadran B & Kuadran C & Kuadran D \\
\hline \multirow{3}{*}{1} & \multirow{3}{*}{ Penumpang } & Jalur Evakuasi & $\begin{array}{l}\text { Pos, Fasilitas dan Petugas } \\
\text { Kesehatan }\end{array}$ & $\begin{array}{l}\text { Pos, Fasilitas dan Kelaikan } \\
\text { Pemeriksaan } \\
\text { Umum }\end{array}$ & Jalur Pejalan Kaki \\
\hline & & $\begin{array}{l}\text { Alat Pemadam } \\
\text { Kebakaran }\end{array}$ & Fasilitas Keamanan & $\begin{array}{l}\text { Fasiitas Perbaikan Ringan } \\
\text { Kendaraan Umum }\end{array}$ & Fasilitas Keselamatan Jalan \\
\hline & & Ruang Tunggu & $\begin{array}{l}\text { Media Pengaduan } \\
\text { Gangguan Keamanan }\end{array}$ & $\begin{array}{ll}\text { Informasi } & \text { Fasilitas } \\
\text { Keselamatan } & \end{array}$ & $\begin{array}{l}\text { Informasi } \\
\text { Kesehatan }\end{array}$ \\
\hline
\end{tabular}




\begin{tabular}{|c|c|c|c|c|c|}
\hline \multirow{11}{*}{ No } & \multirow{11}{*}{ Responden } & \multicolumn{4}{|c|}{ Hasil Diagram Kartesius } \\
\hline & & \multirow{2}{*}{$\begin{array}{l}\text { Kuadran A } \\
\text { Toilet }\end{array}$} & \multirow{2}{*}{$\begin{array}{c}\text { Kuadran B } \\
\text { Petugas Keamanan }\end{array}$} & Kuadran C & Kuadran D \\
\hline & & & & $\begin{array}{lr}\text { Informasi } & \text { Fasilitas } \\
\text { Pemeriksaan dan } & \text { Perbaikan } \\
\text { Ringan Kendaraan Bermotor }\end{array}$ & \begin{tabular}{lrr} 
Kantor & \multicolumn{2}{c}{ Penyelenggara } \\
Terminal, Ruang & Kendali \\
dan Manajemen & Sistem \\
Informasi Terminal &
\end{tabular} \\
\hline & & RTH & Loket Tiket & $\begin{array}{lrr}\text { Jadwal Kedatangan dan } \\
\text { Keberangkatan Kendaraan } \\
\text { Serta Besar Tarif Kendaraan } \\
\text { Bermotor Umum } & \text { Beserta } \\
\text { Realisasi Jadwal } & \text { Secara } \\
\text { Tertulis } & & \\
\end{array}$ & Drainase \\
\hline & & Rumah Makan & Petugas Operasional & \begin{tabular}{lrr} 
Jadwal Kendaraan Umum \\
Dalam Trayek Lanjutan dan \\
Kendaraan Umum Tidak \\
Dalam Trayek Lanjutan \\
Beserta Realisasi Jadwal \\
\multicolumn{2}{l}{ Secara Tertulis } \\
\end{tabular} & Letak Jalur Pemberangkatan \\
\hline & & $\begin{array}{l}\text { Tempat Istirahat } \\
\text { Awak Kendaraan }\end{array}$ & Tempat Ibadah & Area Merokok & Letak Jalur Kedatangan \\
\hline & & Area Internet & Fasilitas Kebersihan & Ruang Baca & Informasi Pelayanan \\
\hline & & $\begin{array}{ll}\text { Tempat } & \text { Penitipan } \\
\text { Barang } & \\
\end{array}$ & Tempat Parkir & Lampu Penerangan Ruang & Informasi Angkutan Jalan \\
\hline & & $\begin{array}{ll}\text { Fasilitas } & \text { Pengisian } \\
\text { Baterai } & \end{array}$ & & $\begin{array}{l}\text { Informasi Gangguan } \\
\text { Perjalanan Kendaraan } \\
\text { Angkutan Umum } \\
\end{array}$ & $\begin{array}{l}\text { Tempat Naik dan Turun } \\
\text { Penumpang }\end{array}$ \\
\hline & & & & & Fasilitas Penyandang Cacat \\
\hline & & & & & Ruang Ibu Menyusui \\
\hline 2 & Supir Bis & Jalur Evakuasi & $\begin{array}{l}\text { Fasilitas Keselamatan } \\
\text { Jalan }\end{array}$ & $\begin{array}{lrr}\text { Jadwal Kedatangan dan } \\
\text { Keberangkatan Kendaraan } \\
\text { Serta Besar Tarif Kendaraan } \\
\text { Bermotor Umum } & \text { Beserta } \\
\text { Realisasi Jadwal } & \text { Secara } \\
\text { Tertulis } & & \\
\end{array}$ & Jalur Pejalan Kaki \\
\hline & & $\begin{array}{l}\text { Alat Pemadam } \\
\text { Kebakaran }\end{array}$ & $\begin{array}{l}\text { Pos, Fasilitas dan Petugas } \\
\text { Kesehatan }\end{array}$ & \begin{tabular}{lrr} 
Jadwal Kendaraan & Umum \\
Dalam Trayek Lanjutan dan \\
Kendaraan Umum Tidak \\
Dalam Trayek Lanjutan \\
Beserta Realisasi Jadwal \\
\multicolumn{2}{l}{ Secara Tertulis } \\
\end{tabular} & Lampu Penerangan Ruang \\
\hline & & $\begin{array}{l}\text { Pos, Fasilitas dan } \\
\text { Kelaikan Pemeriksa } \\
\text { Kendaraan Umum }\end{array}$ & $\begin{array}{ll}\text { Informasi } & \text { Fasilitas } \\
\text { Keselamatan } & \end{array}$ & Ruang Terbuka & Letak Jalur Pemberangkatan \\
\hline & & $\begin{array}{l}\text { Fasilitas Perbaikan } \\
\text { Ringan Kendaraan } \\
\text { Umum }\end{array}$ & $\begin{array}{ll}\text { Informasi } & \text { Fasilitas } \\
\text { Kesehatan } & \end{array}$ & Area Merokok & Letak Jalur Kedatangan \\
\hline & & $\begin{array}{lr}\text { Informasi } & \text { Fasilitas } \\
\text { Pemeriksaan dan } \\
\text { Perbaikan Ringan } \\
\text { Kendaraan Bermotor } \\
\end{array}$ & Fasilitas Keamanan & Ruang Baca & Informasi Pelayanan \\
\hline & & Toilet & $\begin{array}{l}\text { Media Pengaduan } \\
\text { Gangguan Keamanan }\end{array}$ & $\begin{array}{lr}\text { Informasi } & \text { Gangguan } \\
\text { Perjalanan } & \text { Kendaraan } \\
\text { Angkutan Umum } & \\
\end{array}$ & Informasi Angkutan Jalan \\
\hline & & $\begin{array}{l}\text { Tempat Istirahat } \\
\text { Awak Kendaraan }\end{array}$ & Petugas Keamanan & Fasilitas Penyandang Cacat & Ruang Ibu Menyusui \\
\hline & & $\begin{array}{l}\text { Area Yang Tersedia } \\
\text { Jaringan Internet }\end{array}$ & Loket Penjualan Tiket & & \\
\hline & & $\begin{array}{l}\text { Tempat Penitipan } \\
\text { Barang }\end{array}$ & $\begin{array}{l}\text { Kantor Penyelenggara } \\
\text { Terminal, Ruang Kendali } \\
\text { dan Manajemen Sistem } \\
\text { Informasi Terminal }\end{array}$ & & \\
\hline & & & $\begin{array}{ll}\text { Petugas } & \text { Operasional } \\
\text { Terminal } & \\
\end{array}$ & & \\
\hline & & & Ruang Tunggu & & \\
\hline & & & Tempat ibadah & & \\
\hline & & & Rumah Makan & & \\
\hline & & & $\begin{array}{l}\text { Fasilitas dan Petugas } \\
\text { Kebersihan }\end{array}$ & & \\
\hline & & & Drainase & & \\
\hline & & & $\begin{array}{ll}\text { Fasilitas } & \text { Pengisian } \\
\text { Baterai } & \\
\end{array}$ & & \\
\hline & & & $\begin{array}{l}\text { Tempat Naik dan Turun } \\
\text { Penumpang }\end{array}$ & & \\
\hline
\end{tabular}




\begin{tabular}{|c|c|c|c|c|c|}
\hline \multirow{3}{*}{ No } & \multirow{3}{*}{ Responden } & \multicolumn{4}{|c|}{ Hasil Diagram Kartesius } \\
\hline & & Kuadran A & Kuadran B & Kuadran C & Kuadran D \\
\hline & & & $\begin{array}{l}\text { Tempat Parkir } \\
\text { Kendaraan Umum dan } \\
\text { Kendaraan Pribadi }\end{array}$ & & \\
\hline \multirow[t]{23}{*}{3} & \multirow[t]{23}{*}{ Operator Bis } & Jalur Evakuasi & $\begin{array}{l}\text { Fasilitas Keselamatan } \\
\text { Jalan }\end{array}$ & Jalur Pejalan Kaki & $\begin{array}{ll}\text { Lampu } & \text { Penerangan } \\
\text { Ruangan } & \\
\end{array}$ \\
\hline & & $\begin{array}{l}\text { Pos, Fasilitas dan } \\
\text { Kelaikan Pemeriksa } \\
\text { Kendaraan Umum }\end{array}$ & $\begin{array}{ll}\text { Alat } & \text { Pemadam } \\
\text { Kebakaran } & \end{array}$ & $\begin{array}{l}\text { Jadwal Kedatangan Dan } \\
\text { Keberangkatan Kendaraan } \\
\text { Serta Besar Tarif Kendaraan } \\
\text { Bermotor Umum Beserta } \\
\text { Realisasi Jadwal } \\
\text { Tertulis }\end{array}$ & Ruang Ibu Menyusui \\
\hline & & $\begin{array}{lr}\text { Fasilitas } & \text { Perbaikan } \\
\text { Ringan } & \text { Kendaraan } \\
\text { Umum } & \end{array}$ & $\begin{array}{l}\text { Pos, Fasilitas dan Petugas } \\
\text { Kesehatan }\end{array}$ & $\begin{array}{l}\text { Jadwal kendaraan umum } \\
\text { dalam trayek lanjutan dan } \\
\text { kendaraan umum tidak dalam } \\
\text { trayek lanjutan beserta } \\
\text { realisasi jadwal secara tertulis }\end{array}$ & \\
\hline & & $\begin{array}{ll}\text { Ruang } & \text { Terbuka } \\
\text { Hijau } & \\
\end{array}$ & $\begin{array}{ll}\text { Informasi } & \text { Fasilitas } \\
\text { Keselamatan } & \\
\end{array}$ & Area Merokok & \\
\hline & & Rumah Makan & $\begin{array}{ll}\text { Informasi } & \text { Fasilitas } \\
\text { Kesehatan } & \\
\end{array}$ & Ruang Baca & \\
\hline & & $\begin{array}{l}\text { Tempat Istirahat } \\
\text { Awak Kendaraan }\end{array}$ & $\begin{array}{lr}\text { Informasi } & \text { fasilitas } \\
\text { pemeriksaan } & \text { dan } \\
\text { perbaikan ringan } & \text { kendaraan bermotor }\end{array}$ & $\begin{array}{lr}\text { Informasi } & \text { Gangguan } \\
\text { Perjalanan } & \text { Kendaraan } \\
\text { Angkutan Umum } & \end{array}$ & \\
\hline & & $\begin{array}{l}\text { Area Yang Tersedia } \\
\text { Jaringan Internet }\end{array}$ & Fasilitas Keamanan & Fasilitas Penyandang Cacat & \\
\hline & & $\begin{array}{l}\text { Tempat Penitipan } \\
\text { Barang }\end{array}$ & $\begin{array}{l}\text { Media Pengaduan } \\
\text { Gangguan Keamanan }\end{array}$ & & \\
\hline & & $\begin{array}{l}\text { Informasi Angkutan } \\
\text { Jalan }\end{array}$ & Petugas Keamanan & & \\
\hline & & & Loket Penjualan Tiket & & \\
\hline & & & $\begin{array}{l}\text { Kantor Penyelenggara } \\
\text { Terminal, Ruang Kendali } \\
\text { Dan Manajemen Sistem } \\
\text { Informasi Terminal }\end{array}$ & & \\
\hline & & & $\begin{array}{ll}\begin{array}{l}\text { Petugas } \\
\text { Terminal }\end{array} & \text { Operasional } \\
\end{array}$ & & \\
\hline & & & Ruang Tunggu & & \\
\hline & & & Toilet & & \\
\hline & & & Fasilitas Peribadatan & & \\
\hline & & & $\begin{array}{l}\text { Fasilitas dan Petugas } \\
\text { Kebersihan }\end{array}$ & & \\
\hline & & & Drainase & & \\
\hline & & & $\begin{array}{ll}\text { Letak } & \text { Jalur } \\
\text { Pemberangkatan } & \\
\end{array}$ & & \\
\hline & & & Letak Jalur Kedatangan & & \\
\hline & & & Informasi Pelayanan & & \\
\hline & & & $\begin{array}{l}\text { informasi Angkutan } \\
\text { Jalan }\end{array}$ & & \\
\hline & & & $\begin{array}{l}\text { Tempat Naik dan Turun } \\
\text { Penumpang }\end{array}$ & & \\
\hline & & & $\begin{array}{l}\text { Tempat Parkir } \\
\text { Kendaraan Umum dan } \\
\text { Kendaraan Pribadi }\end{array}$ & & \\
\hline
\end{tabular}

\section{Analisis SWOT}

Berikutnya untuk mengoptimalkan peran dan fungsi Terminal Tipe A BRPS maka dilakukan analisis SWOT. Analisis SWOT ini dilakukan berdasarkan faktor internal (kekuatan dan kelemahan) dan faktor eksternal (peluang dan ancaman) pada terminal. 
Tabel 6. IFS Terminal BRPS

\begin{tabular}{|c|c|c|c|c|}
\hline No & Faktor Strategis & Bobot & Rating & Score \\
\hline A & Strength/ Kekuatan & & & \\
\hline 1 & Merupakan Satu Satunya Terminal Tipe A Di Kota Pekanbaru & 0.05 & 4 & 0.20 \\
\hline 2 & Kapasitas Terminal Sangat Memadai & 0.05 & 4 & 0.20 \\
\hline 3 & Trayek Angkutan Umum AKAP Dan AKDP Bervariasi & 0.04 & 3 & 0.12 \\
\hline 4 & Tempat Loket Dan Pertokoan Masih Belum Dipungut Biaya Sewa & 0.03 & 3 & 0.10 \\
\hline 5 & Biaya Parkir Dan Retribusi Masih Gratis & 0.03 & 3 & 0.10 \\
\hline 6 & Terminal Beroperasi 24 Jam Non Stop & 0.03 & 4 & 0.13 \\
\hline 7 & Tersedia Fasilitas Yang Dapat Dikomersilkan & 0.03 & 4 & 0.13 \\
\hline 8 & $\begin{array}{l}\text { Kondisi Bangunan Terminal Masih Relatif Baik, Namun Masih } \\
\text { Memerlukan Perbaikan Ringan Sampai Sedang }\end{array}$ & 0.05 & 4 & 0.20 \\
\hline 9 & Keamanan Di Dalam Area Terminal Sudah Memadai & 0.05 & 4 & 0.20 \\
\hline 10 & Ramah Nya Petugas Operasional Terminal & 0.05 & 4 & 0.20 \\
\hline 11 & Ketersediaan Sumber Daya Manusia Yang Sudah Memadai & 0.05 & 4 & 0.20 \\
\hline 12 & $\begin{array}{l}\text { Masih Adanya Dukungan Anggaran Biaya Perawatan/Perbaikan } \\
\text { Terminal }\end{array}$ & 0.05 & 4 & 0.20 \\
\hline \multicolumn{4}{|c|}{ Jumlah Strength } & 1,94 \\
\hline B & \multicolumn{4}{|l|}{ Weakness/ Kelemahan } \\
\hline 1 & $\begin{array}{l}\text { Fasilitas Terminal Yang Masih Belum Memadai (Rusak Ringan Dan } \\
\text { Beberapa Fasilitas Belum Lengkap) }\end{array}$ & 0.05 & 2 & 0.10 \\
\hline 2 & Masih Terdapat Pelayanan Yang Belum Sesuai Dengan SPM & 0.03 & 2 & 0.07 \\
\hline 3 & Regulasi Yang Belum Pro Dengan Terminal & 0.05 & 1 & 0.05 \\
\hline 4 & $\begin{array}{l}\text { Terbatasnya Jumlah Rute Transportasi Umum Kota Yang Menjangkau } \\
\text { Seluruh Kawasan Menuju Terminal }\end{array}$ & 0.05 & 2 & 0.10 \\
\hline 5 & Biaya Tambahan Untuk Akses Menuju Terminal & 0.05 & 2 & 0.10 \\
\hline 6 & Lokasi Terminal Jauh, Sehingga Mempengaruhi Waktu & 0.05 & 2 & 0.10 \\
\hline 7 & Lemahnya Penegakan Hukum & 0.03 & 1 & 0.03 \\
\hline 8 & Akses Jalan Menuju Gerbang Terminal Sering Banjir & 0.03 & 1 & 0.03 \\
\hline 9 & Jauh Dari Keramaian Atau Fasilitas Bisnis/CBD & 0.03 & 2 & 0.07 \\
\hline 10 & Belum Bisa Menjadi Tempat Transit Oriented Development & 0.04 & 2 & 0.08 \\
\hline 11 & Belum Memiliki Konsep Keterpaduan Antar Moda Dan Intermoda & 0.04 & 2 & 0.08 \\
\hline 12 & $\begin{array}{l}\text { Luasan Terminal Hanya 3,47 Ha, Masih Kurang Dari Standar Yang } \\
\text { Ditentukan Yaitu } 5 \mathrm{Ha}\end{array}$ & 0.03 & 1 & 0.03 \\
\hline \multicolumn{4}{|c|}{ Jumlah Weakness } & $\mathbf{0 , 8 3}$ \\
\hline & Total Skor IFS & 1,00 & & 1,11 \\
\hline
\end{tabular}

Berdasarkan tabel diatas diketahui skor strength dan weaknees adalah 1,94 dan 0,83 dengan total IFS adalah sebesar 1,11.

Tabel 6. EFS Terminal BRPS

\begin{tabular}{|c|c|c|c|c|}
\hline No & Faktor Strategis & Bobot & Rating & Score \\
\hline $\mathbf{C}$ & \multicolumn{4}{|l|}{ Opportunies/ Peluang } \\
\hline 1 & Potensi Demand Cukup Besar & 0.07 & 4 & 0.27 \\
\hline 2 & Potensi Angkutan Yang Masuk Terminal Sangat Besar & 0.07 & 4 & 0.27 \\
\hline 3 & Meningkatnya Pengembangan Lokasi Disekitar Terminal & 0.05 & 3 & 0.14 \\
\hline 4 & Meningkatnya Retribusi (PAD) Di Masa Yang Akan Datang & 0.05 & 3 & 0.14 \\
\hline 5 & $\begin{array}{l}\text { Keterpaduan Moda Angkutan Umum Dengan Simpul Terminal Yang } \\
\text { Lain }\end{array}$ & 0.03 & 3 & 0.10 \\
\hline 6 & Potensi Menjadi Tempat Transit Angkutan Darat & 0.06 & 4 & 0.23 \\
\hline 7 & Jasa Pengiriman Barang & 0.05 & 3 & 0.14 \\
\hline 8 & Dapat Menjadi Role Model Pelayanan Terminal Bis Di Pulau Sumatera & 0.07 & 4 & 0.27 \\
\hline 9 & Dapat Menjadi Pusat Pertumbuhan Kawasan Baru Strategis Kota & 0.07 & 4 & 0.27 \\
\hline 10 & Kesediaan PO Masuk Terminal & 0.07 & 4 & 0.27 \\
\hline \multicolumn{4}{|c|}{ Jumlah Oppoturnies } & 2,10 \\
\hline D & \multicolumn{4}{|l|}{ Treaths/ Ancaman } \\
\hline 1 & Munculnya Terminal Bayangan Di Batas Batas Kota & 0.07 & 2 & 0.14 \\
\hline 2 & Munculnya Angkutan Pesaing Seperti AJAP Dan AJDP & 0.07 & 2 & 0.14 \\
\hline 3 & Pelayanan Antar Jemput Dari/Ke Rumah & 0.05 & 2 & 0.09 \\
\hline 4 & Kemudahan Masyarakat Dalam Mendapatkan Kendaraan Pribadi & 0.07 & 2 & 0.14 \\
\hline 5 & Beberapa Angkutan Umum Ada Yang Tidak Laik Jalan & 0.05 & 1 & 0.05 \\
\hline 6 & $\begin{array}{l}\text { Drainase Sepanjang Jalan Menuju Gerbang Terminal Buruk Dan Dapat } \\
\text { Mengganggu Perjalanan }\end{array}$ & 0.07 & 1 & 0.07 \\
\hline 7 & $\begin{array}{l}\text { Keamanan Diluar Terminal Masih Belum Terjamin Dan Cenderung } \\
\text { Sepi }\end{array}$ & 0.07 & 2 & 0.14 \\
\hline \multicolumn{4}{|c|}{ Jumlah Treaths } & 0,75 \\
\hline & Total Skor EFS & 1,00 & & 1,35 \\
\hline
\end{tabular}


Berdasarkan tabel diatas diketahui skor opportunies dan treaths ialah 2,10 dan 0,75 dengan total EFS ialah sebesar 1,35. Dari hasil analisis internal dan eksternal digambarkan posisi terminal berada pada posisi kuadran I dengan arti Terminal TipeA BRPS disarankan memilih stratetgi agresif dengan memanfaatkan faktor kekuatan dan peluang yang ada pada terminal

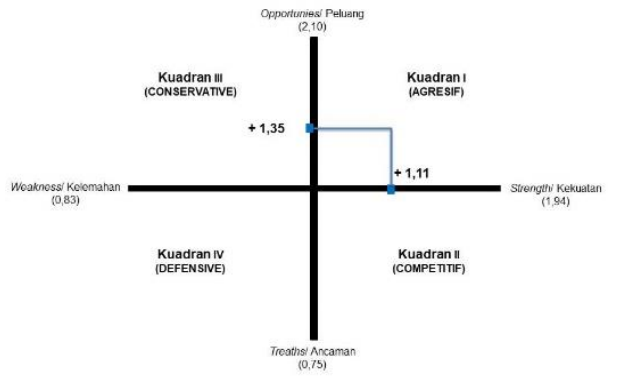

Gambar 5. Matrik SWOT

\section{Analisis Aksesibilitas}

Analisis aksesibilitas terminal digunakan untuk mengetahui ukuran kenyamanan atau kemudahan mengenai cara mencapai terminal, mudah atau susahnya untuk mencapai lokasi terminal tersebut dilihat melalui sistem jaringan transportasi yang ada. Aksesibilitas terminal juga dapat dikaitkan dengan sistem kota yang seperti sistem jaringan, sistem transit kota, dan rute angkutan.

1. Keterkaitan Terminal dengan Sistem Jaringan

Keterpaduan jaringan jalan dan masalah kewenangan sering menjadi polemik di Indonesia tidak terkecuali sistem jaringan jalan penghubung antar kawasan di perkotaan. Terminal tipe A BRPS dihubungkan oleh jalan utama yaitu jalan air hitam (jalan arteri), jalan SM.Amin (jalan kolektor) dan jalan Tuanku Tambunsai (jalan kolektor). Secara eksplisit jika dikaitkan dengan sistem jaringan jalan yang ada terminal ini dihubungkan dengan jaringan jalan yang berskala regional. Sesuai permenhub no.132 tahun 2015 yang mensyaratkan bahwa terminal tipe A harus terletak pada jalan arteri/kolektor dan kelas jalan sekurang kurang nya IIIB maka terminal ini sudah memenuhi peryaratan tersebut.

2. Keterkaitan Terminal dengan Sistem Transit Lokal

Tabel 6. Keterkaitan Terminl dengan Sistem Transit Lokal

\begin{tabular}{|l|l|r|c|}
\hline No & \multicolumn{1}{|c|}{ Sistem Transit Lokal } & $\begin{array}{c}\text { Jarak Dari Terminal } \\
(\mathbf{K m})\end{array}$ & $\begin{array}{c}\text { Cara Pencapaian Langsung } \\
\text { (Dengan Transmetro) }\end{array}$ \\
\hline 1 & Bandara Sultan Syarif Qasim II & 13,3 & $3 \mathrm{x}$ \\
\hline 2 & Pelabuhan Sungai Duku & 13,3 & $2 \mathrm{x}$ \\
\hline
\end{tabular}

Berdasarkan jarak antar sistem transit lokal yang ada di kota pekanbaru, terminal tipe A BRPS memiliki jarak yang cukup jauh yaitu $\pm 13,3 \mathrm{~km}$ dari terminal. Untuk moda transportasi langsung yang terhubung dengan transit lokal belum tersedia sehingga perlu melakukan transit dibeberapa halte untuk menuju tempat tersebut. Dilihat belum terintegrasi nya terminal dengan sistem transit lokal yang ada membuat fungsi terminal sebagai pengumpul dan pengumpan antar moda dan antar transit menjadi menurun dan tidak optimal

3. Keterkaitan Terminal dengan Trayek Angkutan Umum

Aksesibilitas terminal penumpang juga dipengaruhi oleh jumlah rute atau trayek angkutan umum yang masuk ke dalam terminal. Berdasarkan data dari Satuan Pelaksanan Terminal Tipe A BRPS dan Dinas Perhubungan Kota Pekanbaru trayek angkutan umum yang masuk ke terminal sebanyak 86 trayek. Rincian trayek yang masuk ke terminal yaitu 43 trayek AKAP, 39 trayek AKDP, 4 trayek perkotaan, namun untuk trayek angkutan perdesaan belum tersedia atau belum melayani rute menuju terminal

Berdasarkan jumlah trayek yang ada di terminal, yang menyebabkan kurang nya demand penumpang terminal untuk menggunakan terminal sebagai komunal pergerakan ialah 
kurang luasnya cakupan pelayanan angkutan pengumpan yang menuju terminal baik angkutan kota maupun angkutan pedesaan, selain itu belum adanya interkoneksi rute angkutan kota secara langsung antara terminal tipe a dan terminal tipe c yang ada di kota pekanbaru.

\section{Analisis Travel Demand}

Analisis ini menjelaskan jumlah permintaan pergerakan penumpang pada terminal dan proyeksi potensi demand penumpang dimasa yang akan datang. Analisis ini akan dibagi menjadi 2 (dua) yaitu permintaan pergerakan internal/dalam Provinsi Riau dan permintaan perjalanan eksternal/luar Provinsi Riau dengan menyesuaikan fungsi terminal tipe A yang melayani perjalanan AKAP (Antar Kota Antar Provinsi) dan AKDP (Antar Kota Dalam Provinsi).

1. Potensi demand penumpang terminal AKDP

Jumlah Penumpang Terminal AKDP Tahun 2018

8.890 (Kedatangan $)+24.420($ Keberangkatan $)=33.310 /$ tahun

Jumlah Pergerakan Tahun $2018=6.493 .264 /$ tahun

Jumlah Pergerakan Tahun $2028=8.696 .496 /$ tahun

Potensi Demand 2028:

$$
\begin{aligned}
& =\frac{\text { Jumlah Pergerakan Tahun } 2028}{\text { Jumlah Pergerakan Tahun } 2018} \text { X Jumlah Penumpang AKDP } 2018 \\
& =44.612 \text { orang/tahun }
\end{aligned}
$$

Tabel 7. Potensi Penumpang dan Pergerakan AKDP

\begin{tabular}{|l|c|r|r|}
\hline \multirow{2}{*}{ No } & \multirow{2}{*}{ Tahun } & \multicolumn{2}{|c|}{ Potensi Pertambahan Demand AKDP } \\
\cline { 3 - 4 } & 2019 & 6.732 .429 & Penumpang \\
\hline 1 & 2020 & 6.943 .902 & 34.537 \\
\hline 2 & 2021 & 7.162 .976 & 35.622 \\
\hline 3 & 2022 & 7.382 .050 & 36.746 \\
\hline 4 & 2023 & 7.601 .124 & 37.869 \\
\hline 5 & 2024 & 7.820 .199 & 38.993 \\
\hline 6 & 2025 & 8.039 .273 & 40.117 \\
\hline 7 & 2026 & 8.258 .347 & 41.241 \\
\hline 8 & 2027 & 8.477 .421 & 42.365 \\
\hline 9 & 2028 & 8.696 .496 & 43.489 \\
\hline 10 & & & 44.612 \\
\hline
\end{tabular}

Potensi demand penumpang AKDP di Terminal Tipe A BRPS selama 10 tahun yang akan datang memiliki peningkatan potensi demand penumpang sebesar 25,34\% atau 44.612 penumpang dari utilitas terminal saat ini yang berjumlah 33.310 penumpang AKDP/per tahun. Peningkatan potensi demand penumpang AKDP di Terminal Tipe A BRPS tiap tahun rata rata mengalami potensi kenaikan 3,55\%.

2. Potensi demand penumpang terminal AKAP

Jumlah Penumpang Terminal AKAP Tahun 2018

$25.703($ Kedatangan $)+105.880($ Keberangkatan $)=131.583 /$ tahun

Jumlah Pergerakan Tahun $2018=80.290 .673 /$ tahun

Jumlah Pergerakan Tahun $2028=137.507 .360 /$ tahun

Potensi Demand 2028 :

$$
\begin{aligned}
& =\frac{\text { Jumlah Pergerakan Tahun } 2028}{\text { Jumlah Pergerakan Tahun } 2018} \times \text { Jumlah Penumpang AKAP } 2018 \\
& =225.352 \text { orang/tahun }
\end{aligned}
$$


Tabel 7. Potensi Penumpang dan Pergerakan AKDP

\begin{tabular}{|l|c|r|r|}
\hline \multirow{2}{*}{ No } & \multirow{2}{*}{ Tahun } & \multicolumn{2}{|c|}{ Potensi Pertambahan Demand AKAP } \\
\cline { 3 - 4 } & 2019 & 85.841 .018 & Penumpang \\
\hline 1 & 2020 & 91.581 .722 & 140.679 \\
\hline 2 & 2021 & 97.322 .427 & 150.087 \\
\hline 3 & 2022 & 103.063 .132 & 159.495 \\
\hline 4 & 2023 & 108.803 .837 & 168.903 \\
\hline 5 & 2024 & 114.544 .541 & 178.311 \\
\hline 6 & 2025 & 120.285 .246 & 187.719 \\
\hline 7 & 2026 & 126.025 .951 & 197.127 \\
\hline 8 & 2027 & 131.766 .656 & 206.535 \\
\hline 9 & 2028 & 137.507 .360 & 215.944 \\
\hline 10 & & & \\
\hline
\end{tabular}

Potensi demand penumpang AKAP di Terminal Tipe A BRPS selama 10 tahun yang akan datang memiliki peningkatan potensi demand penumpang sebesar $41,61 \%$ atau 225.352 penumpang dari utilitas terminal saat ini yang berjumlah 131.583 penumpang AKAP/pertahun. Peningkatan potensi demand penumpang AKAP di Terminal Tipe A BRPS tiap tahun rata rata mengalami potensi kenaikan $6,46 \%$.

Kapasitas penumpang di Terminal Tipe A BRPS tahun 2018 dapat menampung 3.000 4.000 penumpang/hari, dengan utilitas penumpang AKAP dan AKDP rata rata per hari 452 penumpang/hari terlihat hanya baru $11,3 \%$ okupansi terminal terpenuhi dari aktivitas penumpang.

\section{Analisis Potensi Pendapatan Terminal BRPS}

Potensi pendapatan yang dihitung ialah pendapatan dari penyewaan lahan yang dikomersilkan. Luas kawasan terminal tipe A sesuai Permenhub No. 40 Tahun 2015 ialah 5 Ha untuk terminal yang ada di pulau sumatera dan saat ini terminal tipe A BRPS masih menggunakan lahan 3,47 Ha dengan menyisakan 1,5 Ha yang belum di fungsikan atau dioperasionalkan. Lahan komersil terminal ini terdiri seperti pertokoan/pool bis, rumah makan dan kantin yang dalam eksisting seluas $0,265 \mathrm{Ha}$ atau $2.650 \mathrm{~m} 2$. Setelah itu ada juga lahan kosong yang belum difungsikan atau lahan potensial untuk di sewakan dengan luasan $1,05 \mathrm{Ha}$ atau $10.500 \mathrm{~m} 2$ dengan telah mempertimbangkan $30 \%$ lahan untuk ruang terbuka hijau. Berikut perhitungan potensi pendapatan terminal dari penyewaan lahan;

Luas lahan Komersil Terminal $=0,265 \mathrm{Ha}=2.650 \mathrm{~m} 2$

Luas lahan potensial untuk disewakan/dikembangkan $=1,05 \mathrm{Ha}=10.500 \mathrm{~m} 2$

Potensi harga sewa lahan kawasan terminal $=\mathrm{Rp} .45 .000 / \mathrm{m} 2 /$ tahun

Potensi pendapatan Terminal BRPS $=2.650 \mathrm{~m} 2+10.500 \mathrm{~m} 2=12.650 \mathrm{~m} 2$

$=12.650 \mathrm{~m} 2 \times$ Rp. $45.000 / \mathrm{m} 2 /$ tahun

$=$ Rp. 569.250.000./tahun

Berdasarkan hasil perhitungan potensi pendapatan terminal dari penyewaan lahan yang dikomersilkan dan lahan potensial yang ada, bahwa potensi pendapatan terminal mencapai Rp. 569.250.000/tahun. Potensi pendapatan seperti ini dapat digunakan sebagai pemasukan terhadap terminal dan sebagai percepatan pengoptimalan terminal yang mandiri secara finansial.

\section{Kesimpulan}

Terminal Tipe A BRPS merupakan terminal terbesar di provinsi Riau yang diharapkan dapat tumbuh dan berkembang sebagai terminal pada umum nya yang berfungsi sebagai pengumpul, pengumpan pergerakan penumpang dan moda transportasi darat di kota pekanbaru. Namun dilhat dari pergerakan penumpang dan kendaraan saat ini di terminal baru memenuhi $10 \%$ okupansi baik AKAP dan AKDP dari kapasitas yang disediakan oleh pengelola yang dapat menampung 4000 penumpang dalam sehari. Berdasarkan proyeksi pergerakan di tahun 2028 terminal brps memiliki potensi peningkatan demand penumpang AKDP sejumlah 25,34\% dan peningkatan demand penumpang AKAP sejumlah $41,61 \%$. Untuk pendapatan terminal sendiri JRPWK is licensed under Creative Commons Attribution- 
memiliki potensi dari penyewaan objek objek yang berada dalam kawasan terminal dengan potensi pendapatan penyewaan sejumlah Rp.569.250.000/tahun dan masih bisa bertambah dari retribusi kendaraan dan orang. Dilihat dari standar pelayanan terminal menurut persepsi pengguna terdapat $36,59 \%$ indikator pelayanan yang belum optimal, selain itu penyebab tidak optimalnya terminal ialah dengan belum tersediannya pelayanan angkutan umum yang terintegrasi langsung menuju terminal dari kawasan yang memiliki potensi demand seperti ke kawasan wisata, kawasan perkantoran pemerintah, kawasan permukiman, kawasan hinterland kota dan juga kesimpul transit lokal seperti bandara dan pelabuhan.

Berdasarkan kesimpulan yang telah dipaparkan dalam pembahasan, maka dapat ditarik benang merah nya bahwa terminal tipe A saat ini dalam sisi demand dan pelayanan masih belum memenuhi ekspetasi yang diinginkan sehingga terlihat belum optimal, namun dilihat dari potensi yang ada seperti potensi demand dimasa yang akan datang dan potensi pendapatan yang diperoleh terminal tipe A BRPS dan juga berdasarkan SWOT terminal tipe A BRPS yang berada di kuadran I maka terminal tipe A BRPS Kota Pekanbaru perlu melakukan pengoptimalan dari sisi aspek pelayanan dan pendapatan. Untuk mengoptimalkan terminal dituangkan dalam rekomendasi dibawah ini

Berikutnya ialah upaya untuk mengoptimalkan terminal tipe A BRPS Kota Pekanbaru yang dituangkan dalam rekomendasi sebagai berikut:

1. Perbaikan fisik terminal baik fasilitas utama maupun fasilitas pendukung serta dapat menyesuaikan dengan standar pelayanan minimal

2. Untuk Pemerintah daerah menyediakan layanan Angkutan Kota maupun Angkutan Pedesaan dalam rangka integrasi di dalam terminal sehingga masyarakat tidak kesulitan mendapatkan pelayanan lanjutan.

3. Mendorong terjadinya percepatan pembangunan berbagai jenis sarana pelayanan masyarakat terutama di sekitar kawasan terminal seperti pusat perdagangan, perkantoran swasta, fasilitas pendidikan dan kesehatan dan lain sebagainya

4. Untuk meningkatkan demand Angkutan Umum maka perlu melakukan perbaikan dalam pengelolaan Angkutan Umum terutama AKAP dan AKDP baik masalah kenyamanan, kemananan, ketepatan waktu agar masyarakat mau beralih dari angkutan pribadi ke Angkutan Umum

5. Peningkatan kedipsilinan kepada para pengguna angkutan umum dengan memberikan sanksi yang tegas kepada para pengguna angkutan umum yang tidak mau masuk terminal.

6. Melakukan percepatan pelaksanaan kerjasama dengan sistem perjanjian penyewaan objek objek yang ada didalam kawasan terminal sesuai Permenhub no.71 tahun 2018 Tentang Pelimpahan Sebagian Wewenang dan Tanggung Jawab Pengelolaan Barang Milik Negara (BMN) [8] untuk peningkatan pendapatan terminal dimasa yang akan datang

7. Pemerintah melakukan subsidi terhadap Angkutan umum disaat pandemi covid-19 ini atau pun disaat normal agar standar pelayanan minimal Angkutan dapat terjaga.

\section{Acknowledge}

Demikian penelitian ini peneliti susun, besar harapan agar penelitian ini dapat digunakan sebagai bahan pertimbangan dalam pengoptimalan terminal tipe A BRPS Kota Pekanbaru. Saya ucapkan terima kasih kepada semua pihak yang telah terlibat baik secara moril dan materil dalam proses penyusunan penelitian ini, juga kepada Program Studi Perencanaan Wilayah dan Kota Fakultas Teknik UNISBA yang telah memberikan kesempatan untuk melakukan penelitian pada bahasan ini. Semoga segala usaha dan upaya yang tercurahkan digantikan dengan yang lebih baik lagi. 


\section{Daftar Pustaka}

[1] Adelia, Nita, 2019 Kajian Optimalisasi Fungsi Pelayanan Terminal Kertawangun Kecamatan Sindangagung Kabupaten Kuningan

[2] Agustina, I.H dan Nadya Lingga, 2019. An analysis of the spatial phenomena of women in Cigondewah Fabric Centre, Bandung, Indonesia. IOP Conference Series: Earth and Environmental Science, Volume 447, International Conference on Planning towards Sustainability (ICoPS) 2019 6-7 November 2019, Surakarta, Indonesia. https://iopscience.iop.org/article/10.1088/1755-1315/447/1/012051/meta

[3] Eko Budiharjo. 1997, Tata Ruang Perkotaan, Bandung; Penerbit Alumni.

[4] Mukhsin, D. Agustina, , I. H dan E Fernanda .2020. The study of road network and environment in Indonesia. IOP Conference Series: Materials Science and Engineering, Volume830, Issue3. $\quad$ https://iopscience.iop.org/article/10.1088/1757899X/830/3/032076/meta

[5] Muradi, Dadi. 2005. Pemanfaatan Terminal Angkutan Umum Regional Terkait Dengan Kebijakan Pengembangan Wilayah Kota Pangkal Pinang

[6] Ofyar Z. Tamin. 2000. Perencanaan dan Pemodelan Transportasi. Jurusan Teknik Sipil Institut Teknologi Bandung (Edisi Kedua). Institut Teknologi Bandung

[7] Peraturan Menteri Perhubungan Nomor 40 Tahun 2015 Tentang Standar Pelayanan Terminal Penumpang Angkutan Jalan

[8] Peraturan Menteri Perhubungan Nomor 71 Tahun 2018 Tentang Pelimpahan Sebagian Wewenang dan Tanggung Jawab Pengelolaan Barang Milik Negara (BMN)

[9] Peraturan Menteri Perhubungan Nomor 132 Tahun 2015 Tentang Terminal

[10] Santoso. (2011). Persepsi Konsumen Terhadap Kualitas Bakpao Telo Dengan Metode Importance Performance Analysis (IPA). Jurnal Teknologi Pertanian. 12 (1):9

[11] Sedayu, Agung dkk. 2014. Standar Pelayanan Minimal Terminal Bus Tipe A. Malang : UB Press

[12] Yola,M dan Budianto, D. (2013). Analisis Kepuasan Konsumen Terhadap Kualitas Pelayanan dan Harga Produk Pada Supermarket Dengan Menggunakan Metode Importance dan Performance Analysis (IPA). Jurnal Optimasi Sistem Industri.12(12):301-309 